\title{
Lack of association of genetic variants in genes of the endocannabinoid system with anorexia nervosa
}

Timo Dirk Müller ${ }^{\dagger 1,10}$, Kathrin Reichwald ${ }^{\dagger 1,2}$, Günter Brönner ${ }^{1,3}$, Jeanette Kirschner ${ }^{2}$, Thuy Trang Nguyen ${ }^{4}$, André Scherag ${ }^{4,5}$, Wolfgang Herzog ${ }^{6}$, Beate Herpertz-Dahlmann ${ }^{7}$, Peter Lichtner ${ }^{8,9}$, Thomas Meitinger ${ }^{8,9}$, Matthias Platzer ${ }^{2}$, Helmut Schäfer ${ }^{4}$, Johannes Hebebrand ${ }^{1}$ and Anke Hinney*1

\footnotetext{
Address: ${ }^{1}$ Department of Child and Adolescent Psychiatry, University of Duisburg-Essen, Essen, Germany, ${ }^{2}$ Leibniz Institute for Age Research Fritz Lipmann Institute (FLI), Jena, Germany, ${ }^{3}$ Biocenter of the University of Wuerzburg, Wuerzburg, Germany, ${ }^{4}$ Institute of Medical Biometry and Epidemiology, Philipps-University, Marburg, Germany, ${ }^{5}$ Institute of Medical Informatics, Biometry and Epidemiology, University of DuisburgEssen, Essen, Germany, ${ }^{6}$ Klinik für Psychosomatische und Allgemeine Klinische Medizin, Universitätsklinikum Heidelberg, University of Heidelberg, Germany, ${ }^{7}$ Department of Child and Adolescent Psychiatry and Psychotherapy, University Clinics, Technical University of Aachen, Aachen, Germany, ${ }^{8}$ Institute of Human Genetics, Technical University Munich, Munich, Germany, ${ }^{9} \mathrm{GSF}$ - National Research Center for Environment and Health, München-Neuherberg, Germany and ${ }^{10}$ Department of Psychiatry, University of Cincinnati Genome Research Institute, Cincinnati, OH, USA

Email: Timo Dirk Müller - timo.mueller@uni-due.de; Kathrin Reichwald - kathrinr@fli-leibniz.de; Günter Brönner - broenner@biozentrum.uniwuerzburg.de; Jeanette Kirschner - jkirschn@fli-leibniz.de; Thuy Trang Nguyen - nguyent@med.uni-marburg.de;

André Scherag - Andre.Scherag@uk-essen.de; Wolfgang Herzog - Wolfgang.Herzog@med.uni-heidelberg.de; Beate Herpertz-

Dahlmann - b.herpertz-dahlmann@kjp.rwth-aachen.de; Peter Lichtner - lichtner@gsf.de; Thomas Meitinger - meitinger@gsf.de; Matthias Platzer - mplatzer@fli-leibniz.de; Helmut Schäfer - hsimbe@staff.uni-marburg.de; Johannes Hebebrand - johannes.hebebrand@unidue.de; Anke Hinney* - anke.hinney@uni-due.de

* Corresponding author †Equal contributors
}

Published: 17 November 2008

Child and Adolescent Psychiatry and Mental Health 2008, 2:33 doi:10.1 186/I753-2000-2-33

Received: 6 August 2008

Accepted: 17 November 2008

This article is available from: http://www.capmh.com/content/2/I/33

(C) 2008 Müller et al; licensee BioMed Central Ltd.

This is an Open Access article distributed under the terms of the Creative Commons Attribution License (http://creativecommons.org/licenses/by/2.0), which permits unrestricted use, distribution, and reproduction in any medium, provided the original work is properly cited.

\begin{abstract}
Background: Several lines of evidence indicate that the central cannabinoid receptor I (CNRI) as well as the major endocannabinoid degrading enzymes fatty acid amide hydrolase (FAAH), Nacylethanolamine-hydrolyzing acid amidase (NAAA) and monoglyceride lipase (MGLL) are implicated in mediating the orexigenic effects of cannabinoids. The aim of this study was to analyse whether nucleotide sequence variations in the CNRI, FAAH, NAAA and MGLL genes are associated with anorexia nervosa (AN).

Methods: We analysed the association of a previously described (AAT)n repeat in the 3 ' flanking region of CNRI as well as a total of I5 single nucleotide polymorphisms (SNPs) representative of regions with restricted haplotype diversity in CNRI, FAAH, NAAA or MGLL in up to 91 German AN trios (patient with $\mathrm{AN}$ and both biological parents) using the transmission-disequilibrium-test (TDT). One SNP was additionally analysed in an independent case-control study comprising II3 patients with AN and 178 normal weight controls. Genotyping was performed using matrixassisted laser desorption/ionization time-of-flight mass spectrometry, ARMS-PCR or using 3730xl capillary sequencers.
\end{abstract}


Results: The TDT revealed no evidence for association for any of the SNPs or the (AAT)n repeat with AN (all two-sided uncorrected p-values $>0.05$ ). The lowest $p$-value of 0.1 I was detected for the A-allele of the CNRI SNP rs 1049353 for which the transmission rate was $59 \%$ ( $95 \%$ confidence interval 47\%...70\%). Further genotyping of rs 1049353 in 113 additional independent patients with $\mathrm{AN}$ and 178 normal weight controls could not substantiate the initial trend for association $(\mathrm{p}=$ I.00).

Conclusion: As we found no evidence for an association of genetic variation in CNRI, FAAH, NAAA and MGLL with AN, we conclude that genetic variations in these genes do not play a major role in the etiology of $\mathrm{AN}$ in our study groups.

\section{Background}

Anorexia nervosa (AN) is an eating disorder with unknown etiology. The multifactorial pathogenesis of AN has been emphasized in various studies [1-3]. Accordingly, heritability estimates derived from twin studies revealed that $58-76 \%$ of the variance of $\mathrm{AN}$ can be explained by genetic factors [4]. The highest incidence for the development of AN is around puberty and patients with AN are typically characterized by an abnormal eating behaviour with disturbances of attitudes towards body weight and shape [5]. Therefore, it is reasonable that genetic factors regulating food intake and body weight are implicated in the pathogenesis of AN $[1,2,6,7]$.

One of the endogenous systems that, due to its therapeutic potential in the treatment of obesity, recently reached scientific interest is the endocannabinoid system. Both exogenous (e.g. $\Delta^{9}$-tetrahydrocannabinol) and endogenous cannabinoids (e.g. anandamide and 2-arachidonoylglycerol (2-AG)) stimulate food intake through activation of the cannabinoid receptor 1 (CNR1) [8]. In contrast, inhibition of CNR1 signalling through administration of the selective inverse agonist rimonabant (Acomplia $\left.{ }^{\circledR}\right)$ decreases food intake in both rodents [9-11] and humans [12,13]. The endocannabinoid system further interacts with the leptinergic system; obese rodents with disturbed leptin signal transduction $(o b / o b$ and $d b / d b$ mice as well as $f a / f a$ rats) show elevated levels of anandamide and 2-AG in the hypothalamus. Vice versa, leptin treatment of $o b / o b$ mice decreased hypothalamic levels of both, anandamide and 2-AG [11]. Accordingly, compared to age matched normal weight controls, serum levels of anandamide are increased in patients with AN. Additionally, plasma levels of leptin are negatively correlated with anandamide in both, patients with AN and normal weight healthy controls [2]. In light of these observations, it has previously been suggested that the endocannabinoid system might be implicated in the etiology of AN, in particular through its interaction with the leptinergic system $[2,7]$.

Hypoleptinemia is a cardinal feature of prolonged semistarvation that entails various metabolic and neuroendo- crine alterations which are typically observed in patients with acute AN $[5,14]$ The most prominent neuroendocrine alterations mediated by semi-starvation induced hypoleptinemia include amenorrhea, osteopenia/osteoporosis, and alterations of the hypothalamic-pituitarygonadal (HPG) and -adrenal (HPA) axis [5,14]. Additionally, several lines of evidence indicate that hypoleptinemia entails development of hyperactivity in patients with AN [5,14-18]. However, the implication of the endocannabinoid system in body weight regulation together with its interaction with the leptinergic system makes it a plausible system implicated in the pathogenesis of AN [2,7].

The most prominent endocannabinoids are $\mathrm{N}$-arachidonoylethanolamine (anandamide) [19] and 2-arachidonoylglycerol (2-AG) [20]. Both are synthesised through cells on demand and undergo a rapid degradation through specific hydrolases and lipases $[8,21,22]$. The most prominent endocannabinoid degrading enzymes are the fatty acid amide hydrolase (FAAH), the N-acylethanolamine-hydrolyzing acid amidase (NAAA) and the monoglyceride lipase (MGLL) [23]. FAAH is a membranebound 60-65 $\mathrm{kDa}$ protein that is widely distributed throughout the brain and the periphery $[23,24]$. Under alkaline conditions, FAAH rapidly inhibits the orexigenic effects of anandamide by degrading it to ethanolamine and arachidonic acid $[25,26]$. NAAA is an enzyme with similar function but has, in contrast to FAAH, its pH optimum at 4.5-5 $[27,28]$. The monoglyceride lipase (MGLL) is a serine hydrolase that hydrolyses 2-AG in glycerol and arachidonic acid [22]. As endocannabinoids stimulate food intake through activation of CNR1 and as FAAH, NAAA and MGLL counteract the orexigenic effects of endocannabinoids through their rapid degradation, genetic variation of $C N R 1$ leading to decreased receptor signalling as well as genetic variation of FAAH, NAAA and MGLL leading to increased enzyme activity might be implicated in the etiology of AN.

We performed association studies to analyse whether allelic variation in CNR1, FAAH, NAAA and MGLL is related to the AN phenotype. We therefore genotyped the previously described $(\mathrm{AAT})_{\mathrm{n}}$ repeat in the $3^{\prime}$ flanking 
region of CNR1 as well as a total of 15 SNPs representative of regions with restricted haplotype diversity in CNR1 (rs2180619, rs806379, rs1535255, rs2023239 and rs1049353), FAAH (rs932816, rs324420, rs324419, rs2295632 and rs873978), NAAA (rs2292534, rs6532046, rs10518142 and rs874546) and MGLL (rs893294) in up to 91 German AN trios (patient with AN and both biological parents). Genotyping was performed using matrix-assisted laser desorption/ionization time-offlight mass spectrometry or allele specific polymerase chain reaction (ARMS-PCR). The $\mathrm{AAT}_{14}$ repeat allele of CNR1 has recently been found to be associated with the binge eating/purging type of $\mathrm{AN}$ whereby the $\mathrm{AAT}_{13}$ repeat allele tended to be preferentially transmitted to patients with the restricting type of AN [29]. Furthermore, SNP rs324420 (c.385C/A) in the FAAH gene, leading to decreased enzyme activity and thus increased levels of endocannabinoids and presumably increased food intake, was recently found to be associated with obesity [30] and drug abuse [31]. The CNR1 haplotype comprising the minor alleles of SNP rs806379 (T-allele), rs1535255 (G-allele) and rs2023239 (C-allele) has further been shown to be associated with drug and alcohol abuse in European and African Americans [32].

\section{Methods}

The ascertainment strategy was previously described in detail [33]. Written informed consent was given by all participants and in the case of minors, by their parents. The study was approved by the ethics committees of the Universities of Marburg and Duisburg-Essen and carried out according to the Declaration of Helsinki.

Study group 1 (AN trios) comprised 91 (3 male) patients with AN (mean age $15.72 \pm 2.04$ years, mean BMI $15.42 \pm$ $2.39 \mathrm{~kg} / \mathrm{m}^{2}$ ) and both biological parents (mean age 46.73 \pm 5.67 , mean BMI $\left.26.22 \pm 4.16 \mathrm{~kg} / \mathrm{m}^{2}\right)$.

Study group 2 (cases and controls) included 204 patients with AN (113 patients with AN independent from study group 1). The 113 (7 male) independent patients included 65 ( 3 male) individuals with acute AN and 48 (4 male) individuals from a catamnestic study with a history of AN. The acute patients had a mean age of $22.47 \pm 11.67$ years and a mean BMI of $14.81 \pm 2.29 \mathrm{~kg} / \mathrm{m}^{2}$. The catamnestic individuals had a mean age of $33.60 \pm 7.22$ years and a mean BMI of $20.78 \pm 2.05 \mathrm{~kg} / \mathrm{m}^{2}$. In total, the 204 (10 male) patients had a mean age of $22.13 \pm 10.03$ years, a mean BMI of $16.46 \pm 3.30 \mathrm{~kg} / \mathrm{m}^{2}$. The control group comprised 178 healthy normal weight individuals with a mean age of $24.58 \pm 2.56$ years and a mean BMI of 21.76 $\pm 1.08 \mathrm{~kg} / \mathrm{m}^{2}$. All patients with AN fulfilled the diagnostic criteria for AN according to the diagnostic and statistical manual of mental disorders (DSM-IV) [34].
Genotyping was performed using matrix-assisted laser desorption/ionization time-of-flight mass spectrometry (MALDI-TOF MS, Sequenom, San Diego, CA). Only the CNR1 SNP rs1049353 was genotyped using ARMS-PCR as described previously [35]. The CNR1 (AAT) trinucleotide repeat was genotyped using 3730xl capillary sequencers (Applied Biosystems) and GeneMapper software (Version 4.0, Applied Biosystems). Primers for analyses of CNR1 variations were derived from genomic entry AL136096.7; rs $1049353 \mathrm{~F}_{\text {out }}$ : 5'-GGA CTC GGA CTG CCT GCA CAA A3'; $\mathrm{R}_{\text {out }}$ : 5'-AAA TTC TTT TCC TGT GCT GCC AGG G-3', $\mathrm{F}_{\mathrm{in}}$ : 5'-CAG AAA GCT GCA TCA AGA GCC CG-3', $\mathrm{R}_{\mathrm{in}}$ : 5'GAC ATG GTT ACC TTG GCA ATC TTG CCT-3' (product size outer primers: 175 bp, G-allele: 120 bp, A-allele: 105 bp); (AAT) trinucleotide repeat: F (FAM-labelled): 5'-CCT TCT CCC AGC ACA ATC AT-3', R: 5'-TAC ATC TCG GTG TGT GAT GTT CC A TGT TCC-3' (PCR-product size based on genomic entry AL136096.7: 277 bp). SNP assays for analyses with MALDI-TOF mass spectrometry were designed with the SpectroDesigner software (Sequenom). For validity of genotypes, alleles were rated independently by at least two experienced individuals. Discrepancies were resolved unambiguously either by reaching consensus or by retyping.

The family-based association analyses were done applying transmission disequilibrium tests (TDT) [36] while the software FAMHAP (v16; http://www.uni-bonn.de/ numte70e/becker.html) was used to investigate the haplotypes consisting of the genotyped SNPs within the respective genes. Power considerations for the A-allele of rs1049353 were performed using the program Quanto ( $\mathrm{v}$ 1.2.3; http://hydra.usc.edu/gxe) at the one-sided significance level of 0.05 . Here, we assumed an AN prevalence of $0.5 \%$ and an allele frequency of 0.26 (accoding to http:// www.hapmap.org, CEU sample). Exact Cochran-Armitage trend test, implemented in SAS, was applied to test for association of the CNR1 SNP rs1049353 in case-control data. If not indicated otherwise, all reported p-values are two-sided and were not corrected for multiple testing as none of the null hypotheses was rejected. A significance level of $\alpha=0.05$ (two-sided) was applied.

\section{Results}

The Transmission-Disequilibrium Test (TDT) revealed no indication for an association of the analysed SNPs or the $(\mathrm{AAT})_{\mathrm{n}}$ repeat with AN (Table 1$)$. For the A-allele of the CNR1 SNP rs1049353 the lowest p-value was 0.11 for an estimated transmission rate of 59\% (95\% confidence interval 47\%...70\%). Applying conditional logistic regression on the trio data, we obtained a multiplicative OR of the A-allele at 1.43 (95\% confidence interval $0.91 \ldots 2.25)$. Hence, in assuming a true effect of such size the power of our consecutive case-control study comprising 113 additional independent patients with AN and 178 normal 
Table I: Genotypes and TDT results of the analysed variants in CNRI. NAAA and MGLL in the AN trios

\begin{tabular}{|c|c|c|c|c|c|c|c|c|}
\hline Gene & SNPI,2 & Alleles $^{3}$ major/minor & Location Exchange & $\mathbf{N}^{4}$ & Genotypes (\%) 5 & Allele frequ. ${ }^{6}$ & Transm. rate ${ }^{7}$ & p-value ${ }^{8}$ \\
\hline & & & & & A/A 26 (42.62) & A: 0.64 & & \\
\hline & & & & & A/G 26 (42.62) & & & \\
\hline \multirow[t]{3}{*}{ CNRI } & rs2180619 & $-22,959 \mathrm{~A} / \mathrm{G}$ & Putative promoter & 61 & G/G 9 (I4.75) & G: 0.36 & $0.49(\mathrm{G})$ & 1.00 \\
\hline & & & & & A/A $16(26.23)$ & A: 0.55 & & \\
\hline & & & & & $\mathrm{A} / \mathrm{T} 35$ (57.38) & & & \\
\hline \multirow[t]{3}{*}{ CNRI } & rs806379 & $-6,274 \mathrm{~A} / \mathrm{T}$ & Intron 2 & 61 & T/T 10 (16.39) & $\mathrm{T}: 0.45$ & $0.52(\mathrm{~T})$ & 0.90 \\
\hline & & & & & $\mathrm{T} / \mathrm{T} 43$ (70.49) & $\mathrm{T}: 0.84$ & & \\
\hline & & & & & T/G I6 (26.23) & & & \\
\hline \multirow[t]{3}{*}{ CNRI } & rs 1535255 & $-6,215 T / G$ & Intron 2 & 61 & G/G $2(3.28)$ & G: 0.16 & $0.50(\mathrm{G})$ & 1.00 \\
\hline & & & & & $\mathrm{T} / \mathrm{T} 43$ (70.49) & $\mathrm{T}: 0.84$ & & \\
\hline & & & & & T/C $16(26.23)$ & & & \\
\hline \multirow[t]{3}{*}{ CNRI } & rs2023239 & $-5,489 \mathrm{~T} / \mathrm{C}$ & $\begin{array}{c}\text { Exon } 3 \\
\text { Non-coding }\end{array}$ & 61 & C/C $2(3.28)$ & C: 0.16 & $0.50(\mathrm{C})$ & 1.00 \\
\hline & & & & & G/G 38 (4I.76) & G: 0.65 & & \\
\hline & & & & & G/A $43(47.25)$ & & & \\
\hline \multirow[t]{3}{*}{ CNRI } & rs1049353 & I,359G/A & $\begin{array}{c}\text { Exon } 4 \\
\text { Thr453Thr }\end{array}$ & 91 & A/A 10 (10.99) & A: 0.35 & $0.59(\mathrm{~A})$ & 0.11 \\
\hline & & & & & G/G $33(54.10)$ & G: 0.75 & & \\
\hline & & & & & G/A 26 (42.62) & & & \\
\hline \multirow[t]{3}{*}{ FAAH } & rs932816 & $-272 G / A$ & $\begin{array}{l}\text { Putative } \\
\text { promoter }\end{array}$ & 61 & A/A 2 (3.28) & A: 0.25 & $0.39(\mathrm{~A})$ & 0.13 \\
\hline & & & & & C/C 40 (66.67) & C: 0.80 & & \\
\hline & & & & & C/A I6 (26.67) & & & \\
\hline \multirow[t]{3}{*}{ FAAH } & rs324420 & $|0,74| C / A$ & $\begin{array}{c}\text { Exon } 3 \\
\text { Thr I 29Pro }\end{array}$ & 60 & A/A 4 (6.67) & A: 0.20 & $0.56(\mathrm{~A})$ & 0.61 \\
\hline & & & & & G/G 49 (80.33) & G: 0.89 & & \\
\hline & & & & & G/A II (I8.03) & & & \\
\hline \multirow[t]{3}{*}{ FAAH } & rs324419 & $11,966 \mathrm{G} / \mathrm{A}$ & $\begin{array}{c}\text { Exon } 7 \\
\text { Cys299Cys }\end{array}$ & 61 & $\mathrm{~A} / \mathrm{A} I(\mathrm{I} .64)$ & A: 0.11 & $0.59(\mathrm{~A})$ & 0.52 \\
\hline & & & & & G/G 60 (98.36) & G: 0.99 & & \\
\hline & & & & & G/A I (I.64) & & & \\
\hline \multirow[t]{3}{*}{$F A A H$} & rs873978 & I3,883G/A & Intron 7 & 61 & $\mathrm{~A} / \mathrm{A} 0(0.00)$ & $A: 0.01$ & $1.00(\mathrm{~A})$ & 1.00 \\
\hline & & & & & C/C $34(56.67)$ & C: 0.73 & & \\
\hline & & & & & C/A 20 (33.33) & & & \\
\hline \multirow[t]{3}{*}{ FAAH } & rs2295632 & $19,542 \mathrm{C} / \mathrm{A}$ & 3'UTR & 60 & A/A $6(10.0)$ & A: 0.27 & $0.42(\mathrm{~A})$ & 0.42 \\
\hline & & & & & G/G 34 (56.67) & G: 0.75 & & \\
\hline & & & & & G/A 22 (36.67) & & & \\
\hline \multirow[t]{3}{*}{ NAAA } & rs2292534 & $368 \mathrm{~A} / \mathrm{G}$ & Intron I & 60 & $\mathrm{~A} / \mathrm{A} 4$ (6.67) & A: 0.25 & $0.57(\mathrm{~A})$ & 0.42 \\
\hline & & & & & $\mathrm{A} / \mathrm{A} 38(62.30)$ & A: 0.78 & & \\
\hline & & & & & $\mathrm{A} / \mathrm{T} 19(31.15)$ & & & \\
\hline \multirow[t]{3}{*}{ NAAA } & rs4859567 & $9,263 \mathrm{~A} / \mathrm{T}$ & Intron 3 & 61 & $\mathrm{~T} / \mathrm{T} 4(6.56)$ & $\mathrm{T}: 0.22$ & $0.43(\mathrm{~T})$ & 0.42 \\
\hline & & & & & G/G $36(60.00)$ & G: 0.78 & & \\
\hline & & & & & $\mathrm{G} / \mathrm{T} 21$ (35.00) & & & \\
\hline \multirow[t]{2}{*}{$N A A A$} & rs 10518142 & $19,229 \mathrm{G} / \mathrm{T}$ & Intron 5 & 60 & $\mathrm{~T} / \mathrm{T} 3(5.00)$ & $\mathrm{T}: 0.22$ & $0.63(\mathrm{~T})$ & 0.13 \\
\hline & & & & & C/C 22 (36.07) & $C: 0.61$ & & \\
\hline
\end{tabular}


Table I: Genotypes and TDT results of the analysed variants in CNRI. NAAA and MGLL in the AN trios (Continued)

\begin{tabular}{|c|c|c|c|c|c|c|c|c|}
\hline \multirow[b]{2}{*}{ NAAA } & \multirow[b]{2}{*}{ rs6819442 } & \multicolumn{7}{|c|}{$\mathrm{C} / \mathrm{T} 3 \mathrm{I}(50.82)$} \\
\hline & & $22,995 \mathrm{C} / \mathrm{T}$ & Intron 9 & 61 & T/T 8 (I3.II) & T: 0.39 & $0.56(\mathrm{~T})$ & 0.42 \\
\hline & & & & & T/T 36 (59.02) & $\mathrm{T}: 0.75$ & & \\
\hline & & & & & T/A 19 (3I.15) & & & \\
\hline MGLL & rs893294 & I2I,143T/A & Intron 8 & 61 & A/A 6 (9.84) & A: 0.25 & $0.54(\mathrm{~A})$ & 0.75 \\
\hline
\end{tabular}

I All SNPs were tested for Hardy-Weinberg equilibrium (exact $p \geq 0.05$ ); ${ }^{2}$ The TGC haplotype comprises the minor alleles of $r s 806379$, $r s$ I535255, and rs2023239; ${ }^{3}$ Numbers are given according to genomic entry ALI 36096.7 and the translation start codon (nt+I is the A of ATG); SNP alleles correspond to dbSNP http://www.ncbi.nlm.nih.gov/SNP/; ${ }^{4}$ Number of anorexia nervosa trios genotyped; 5 Genotype frequencies in the patients with AN; ${ }^{6}$ Allele frequencies in the patients with $\mathrm{AN} ;{ }^{7}$ Transmission rate of the minor alleles; ${ }^{8}$ for TDT

weight controls would be about $60 \%$. The initial finding, however, could not be substantiated by the case-control approach (exact $\mathrm{p}=1.00$ ). Similarly, a combined casecontrol analysis including the 91 patients from the familytrios (204 patients with AN and 178 controls) revealed no association of the A-allele of rs1049353 with the AN phenotype (exact $\mathrm{p}=0.27$; multiplicative OR $1.20 ; 95 \% \mathrm{CI}$ $0.88 \ldots 1.65)$.

The CNR1 haplotype comprising the minor alleles of rs806379, rs1535255 and rs2023239 (TGC), previously found to be associated with polysubstance abuse in European and African Americans [32], revealed likewise no evidence for an association with AN in our study groups. The allele frequencies of the CNR1 AAT trinucleotide repeat were in accordance to previous results $[29,37,38]$. However, the $\mathrm{AAT}_{13}$ and $\mathrm{AAT}_{14}$ repeat alleles, previously found to be preferentially transmitted to the restricting and binge eating/purging type of AN, respectively, [29] did not indicate evidence for an association with AN in our samples (the global test for transmission disequilibrium indicated $\mathrm{p}=0.35$ ). Further haplotype analyses resulted in lack of transmission disequilibrium for all haplotypes, including those solely comprising frequently transmitted alleles ( $\mathrm{p}$ of global test for haplotypes of five CNR1 SNPs: 0.66; five FAAH SNPs: 0.45 and four NAAA SNPs: 0.72).

\section{Discussion}

We observed no evidence for a transmission disequilibrium for any of the 15 analysed SNPs in CNR1, FAAH, NAAA or MGLL as assessed by the TDT. The strongest effect with an estimated transmission rate of 59\% hinting at a preferential transmission of the CNR1 rs1049353 Aallele to patients with AN was not substantiated in a subsequent case-control study comprising 113 independent patients with AN and 178 healthy controls. Also, combining the 113 independent patients with AN with the 91 patients from study group 1 did not alter this lack of evidence for an association of the rs1049353 A-allele to patients with AN. Contrary to our initial expectation of an effect size of 1.43 estimated from the trio sample, the true effect of this allele may be more moderate to be detected by our, even pooled, relatively small case-control sample.
Even though the CNR1 SNP rs1049353 has not been analysed in patients with AN before, the G-allele of rs 1049353 was recently found to be associated with obesity in a small case-control study comprising obese and normal weight Italians [39]. However, several other studies could not confirm this finding [35,40,41]. The CNR1 TGC haplotype previously found to be associated with polysubstance abuse in European and African Americans [32] revealed likewise no evidence for a transmission disequilibrium in our samples. Also the $\mathrm{AAT}_{14}$ and $\mathrm{AAT}_{13}$ repeat alleles of CNR1, which has previously been reported to be preferentially transmitted in patients with the binge eating/purging or restricting type of AN, respectively, were not found to be preferentially transmitted to patients with AN in our study. However, it has to be considered that the moderate to low sample size used in this study might have contributed to the observed lack of association. Additionally, it can not be ruled out that other variants, that are not in linkage disequilibrium with the here analysed variants, might contribute to the pathogenesis of AN.

Exogenous and endogenous cannabinoids stimulate food intake and promote weight gain in both, rodents [42] and humans [12,13]. Oral application of $\Delta^{9}$-THC further increases food intake and entails weight restoration in cachectic patients receiving cancer chemotherapy $[43,44]$. Only one small trial comprising 11 (of which three dropped out) patients with AN has focused on body weight gain after treatment with $\Delta^{9}$-THC and found no effect of oral application of $\Delta^{9}$-THC in doses up to $30 \mathrm{mg} /$ day on body weight gain after four weeks of treatment [45]. However, in light of the small sample size, this observation has to be regarded with caution, especially as THC induced weight gain was compared to diazepam, for which animal studies also indicate a stimulation of body weight gain after its application $[46,47]$.

Various association studies for AN have, with only limited success, focused on genes implicated in the regulation of food intake, as e.g. on the genes coding for leptin [48], the leptin receptor $(O b R b)$ [49], ghrelin [50,51], the brain derived neurotrophic factor $(B D N F)$ [52-55] or the tumor necrosis factor-alpha (TNF- $\alpha$ ) [56]. Most of the respective 
studies yielded negative results. However, Ribases et al. (2003) reported strong association of the Val66Met polymorphism of BDNF with the restricting type of AN [52]. Additionally, this variant was associated with minimum BMI in these patients [52]. Replication analyses of this variant in 1,142 Caucasian patients with eating disorders from five European countries confirmed the association of this variant with all eating disorder subtypes including AN, AN-restricting type, AN-binge-eating/purging type and $\mathrm{BN}$ [53]. However, not all studies were able to confirm this finding [55].

\section{Conclusion}

In summary, we did not find evidence for an association of the (AAT) $)_{n}$ repeat and several SNPs in CNR1, FAAH, NAAA and MGLL with AN in our samples. We thus conclude that the here analysed variations in CNR1, FAAH, $N A A A$ and MGLL at least do not seem to play a major role in the genetic etiology of AN in our study groups.

\section{Competing interests}

The authors declare that they have no competing interests.

\section{Authors' contributions}

TDM carried out the allele specific PCR, participated in design and interpretation of data and drafted the manuscript. KR and JK carried out the capillary sequencing. KR further participated in design and interpretation of data and revised the manuscript critically. GB participated in the design and interpretation of data. TTN and AS performed the statistical analysis under supervision of HS. $\mathrm{WH}$ and BH-D participated in patient recruitment and interpretation of data. PL and TM carried out the molecular genetic studies using MALDI-TOF mass spectrometry. $\mathrm{JH}$ and AH conceived the design and participated in coordination and interpretation of data; helped to draft the manuscript and revised it critically.

\section{Acknowledgements}

This work was supported by grants from the Federal Ministry of Education and Research (NGFN2: 0I GS0482, 0I GS0483; NGFNPlus: 0I GS0820), the European Union (FP6 LSHMCT-2003-50304I) and the Deutsche Forschungsgemeinschaft (DFG; HE I446/4-I). The skillful technical assistance of Jitka Andrae is highly appreciated.

\section{References}

I. Hinney A, Friedel S, Remschmidt H, Hebebrand J: Genetic risk factors in eating disorders. Am J Pharmacogenomics 2004, 4:209-223.

2. Monteleone P, Matias I, Martiadis V, De Petrocellis L, Maj M, Di Marzo $\checkmark$ : Blood levels of the endocannabinoid anandamide are increased in anorexia nervosa and in binge-eating disorder, but not in bulimia nervosa. Neuropsychopharmacology 2005, 30:1216-1221.

3. Bulik CM, Hebebrand J, Keski-Rahkonen A, Klump KL, ReichbornKjennerud T, Mazzeo SE, Wade TD: Genetic epidemiology, endophenotypes, and eating disorder classification. Int J Eat Disord 2007, 40(Suppl):S52-60.

4. Klump KL, Miller KB, Keel PK, McGue M, lacono WG: Genetic and environmental influences on anorexia nervosa syndromes in a population-based twin sample. Psychol Med 200I, 3 I:737-740.
5. Hebebrand J, Muller TD, Holtkamp K, Herpertz-Dahlmann B: The role of leptin in anorexia nervosa: clinical implications. Mol Psychiatry 2007, I 2:23-35.

6. Halmi KA: Eating disorders in females: genetics, pathophysiology, and treatment. J Pediatr Endocrinol Metab 2002, I5(Suppl 5): $1379-1386$.

7. Støving RK, Andries A, Brixen K, Flyvbjerg A, Hørder K, Frystyk J: Leptin, ghrelin, and endocannabinoids: Potential therapeutic targets in anorexia nervosa. J Psychiatr Res 2008.

8. Di Marzo V, Bifulco M, De Petrocellis $L$ : The endocannabinoid system and its therapeutic exploitation. Nat Rev Drug Discov 2004, 3:77I-784.

9. Colombo G, Agabio R, Diaz G, Lobina C, Reali R, Gessa GL: Appetite suppression and weight loss after the cannabinoid antagonist SR I4I7 I6. Life Sci 1998, 63:PLI I 3-II7.

10. Liu YL, Connoley IP, Wilson CA, Stock MJ: Effects of the cannabinoid CBI receptor antagonist SRI4I7I6 on oxygen consumption and soleus muscle glucose uptake in Lep(ob)/ Lep(ob) mice. Int J Obes (Lond) 2005, 29: 183-187.

II. Di Marzo V, Goparaju SK, Wang L, Liu J, Bátkai S, Járai Z, Fezza F, Miura GI, Palmiter RD, Sugiura T, Kunos G: Leptin-regulated endocannabinoids are involved in maintaining food intake. Nature 200I, 4I 0:822-825.

12. van Gaal LF, Rissanen AM, Scheen AJ, Ziegler O, Rössner S, RIOEurope Study Group: Effects of the cannabinoid-I receptor blocker rimonabant on weight reduction and cardiovascular risk factors in overweight patients: I-year experience from the RIO-Europe study. Lancet 2005, 365:1389-1397.

13. Després JP, Golay A, Sjöström L, Rimonabant in Obesity-Lipids Study Group: Effects of rimonabant on metabolic risk factors in overweight patients with dyslipidemia. N Engl J Med 2005, 353:2I $21-2134$.

14. Hebebrand J, Exner C, Hebebrand K, Holtkamp C, Casper RC, Remschmidt $\mathrm{H}$, Herpertz-Dahlmann B, Klingenspor M: Hyperactivity in patients with anorexia nervosa and in semistarved rats: evidence for a pivotal role of hypoleptinemia. Physiol Behav 2003, 79:25-37.

15. Exner C, Hebebrand J, Remschmidt H, Wewetzer C, Ziegler A, Herpertz S, Schweiger U, Blum WF, Preibisch G, Heldmaier G, Klingenspor $M$ : Leptin suppresses semi-starvation induced hyperactivity in rats: implications for anorexia nervosa. Mol Psychiatry 2000, 5:476-48I.

16. Holtkamp K, Herpertz-Dahlmann B, Mika C, Heer M, Heussen N, Fichter M, Herpertz S, Senf W, Blum WF, Schweiger U, Warnke A, Ballauff A, Remschmidt H, Hebebrand J: Elevated physical activity and low leptin levels co-occur in patients with anorexia nervosa. J Clin Endocrinol Metab 2003, 88:5 I69-5 I74.

17. Holtkamp K, Hebebrand J, Herpertz-Dahlmann B: The contribution of anxiety and food restriction on physical activity levels in acute anorexia nervosa. Int J Eat Disord 2004, 36:163-171.

18. Holtkamp K, Herpertz-Dahlmann B, Hebebrand K, Mika C, Kratzsch J, Hebebrand J: Physical activity and restlessness correlate with leptin levels in patients with adolescent anorexia nervosa. Biol Psychiatry 2006, 60:3II-3I3.

19. Devane WA, Hanus L, Breuer A, Pertwee RG, Stevenson LA, Griffin G, Gibson D, Mandelbaum A, Etinger A, Mechoulam R: Isolation and structure of a brain constituent that binds to the cannabinoid receptor. Science 1992, 258: 1946-1949.

20. Sugiura T, Kondo S, Sukagawa A, Nakane S, Shinoda A, Itoh K, Yamashita A, Waku K: 2-Arachidonoylglycerol: a possible endogenous cannabinoid receptor ligand in brain. Biochem Biophys Res Commun 1995, 21 5:89-97.

21. Di Marzo $\mathrm{V}$ : Biosynthesis and inactivation of endocannabinoids: relevance to their proposed role as neuromodulators. Life Sci 1999, 65:645-655.

22. Dinh TP, Freund TF, Piomelli D: A role for monoglyceride lipase in 2-arachidonoylglycerol inactivation. Chem Phys Lipids 2002, I $21:$ | 149-158.

23. Puffenbarger RA: Molecular biology of the enzymes that degrade endocannabinoids. Curr Drug Targets CNS Neurol Disord 2005, 4:625-63I.

24. Hillard CJ, Wilkison DM, Edgemond WS, Campbell WB: Characterization of the kinetics and distribution of $\mathrm{N}$-arachidonylethanolamine (anandamide) hydrolysis by rat brain. Biochim Biophys Acta 1995, I 257(3):249-256. 
25. Cravatt BF, Giang DK, Mayfield SP, Boger DL, Lerner RA, Gilula NB: Molecular characterization of an enzyme that degrades neuromodulatory fatty-acid amides. Nature 1996, 384:83-87.

26. Cravatt BF, Demarest K, Patricelli MP, Bracey MH, Giang DK, Martin $B R$, Lichtman $A H$ : Supersensitivity to anandamide and enhanced endogenous cannabinoid signaling in mice lacking fatty acid amide hydrolase. Proc Natl Acad Sci USA 200I, 98:937I-9376.

27. Tsuboi K, Sun YX, Okamoto Y, Araki N, Tonai T, Ueda N: Molecular characterization of $\mathbf{N}$-acylethanolamine-hydrolyzing acid amidase, a novel member of the choloylglycine hydrolase family with structural and functional similarity to acid ceramidase. J Biol Chem 2005, 280: I I082-I 1092.

28. Tsuboi K, Takezaki N, Ueda N: The $\mathbf{N}$-acylethanolamine-hydrolyzing acid amidase (NAAA). Chem Biodivers 2007, 4: | 9|4- 1925.

29. Siegfried Z, Kanyas K, Latzer Y, Karni O, Bloch M, Lerer B, Berry EM: Association study of cannabinoid receptor gene (CNRI) alleles and anorexia nervosa: differences between restricting and binging/purging subtypes. Am J Med Genet B Neuropsychiatr Genet 2004, I 25B: I 26-130.

30. Sipe JC, Waalen J, Gerber A, Beutler E: Overweight and obesity associated with a missense polymorphism in fatty acid amide hydrolase (FAAH). Int J Obes (Lond) 2005, 29:755-759.

31. Sipe JC, Chiang K, Gerber AL, Beutler E, Cravatt BF: A missense mutation in human fatty acid amide hydrolase associated with problem drug use. Proc Natl Acad Sci USA 2002, 99:8394-8399.

32. Zhang PW, Ishiguro H, Ohtsuki T, Hess J, Carillo F, Walther D, Onaivi ES, Arinami T, Uhl GR: Human cannabinoid receptor I: 5' exons, candidate regulatory regions, polymorphisms, haplotypes and association with polysubstance abuse. Mol Psychiatry 2004, 9:916-931.

33. Hinney A, Lentes KU, Rosenkranz K, Barth N, Roth H, Ziegler A, Hennighausen K, Coners H, Wurmser H, Jacob K, Römer G, Winnikes U, Mayer H, Herzog W, Lehmkuhl G, Poustka F, Schmidt MH, Blum WF, Pirke KM, Schäfer H, Grzeschik KH, Remschmidt H, Hebebrand ): Beta 3-adrenergic-receptor allele distributions in children, adolescents and young adults with obesity, underweight or anorexia nervosa. Int J Obes Relat Metab Disord 1997, 2 I:224-230.

34. American Psychiatric Association: Diagnostic and statistical manual of mental disorders (DSM-IV). Washington, DC; 1994:539-549.

35. Müller TD, Reichwald K, Wermter AK, Brönner G, Nguyen TT, Friedel S, Koberwitz K, Engeli S, Lichtner P, Meitinger T, Schäfer H, Hebebrand J, Hinney A: No evidence for an involvement of variants in the cannabinoid receptor gene (CNRI) in obesity in German children and adolescents. Mol Genet Metab 2007, 90:429-434

36. Spielman RS, McGinnis RE, Ewens WJ: Transmission test for linkage disequilibrium: the insulin gene region and insulindependent diabetes mellitus (IDDM). Am J Hum Genet 1993, 52:506-5I6.

37. Comings DE, Muhleman D, Gade R, Johnson P, Verde R, Saucier G, MacMurray J: Cannabinoid receptor gene (CNRI): association with i.v. drug use. Mol Psychiatry 1997, 2:161-168.

38. Covault J, Gelernter J, Kranzler H: Association study of cannabinoid receptor gene (CNRI) alleles and drug dependence. Mol Psychiatry 200I, 6:501-502.

39. Gazzerro P, Caruso MG, Notarnicola M, Misciagna G, Guerra V, Laezza C, Bifulco M: Association between cannabinoid type-I receptor polymorphism and body mass index in a southern Italian population. Int J Obes (Lond) 2007, 3 I:908-91 2.

40. Peeters A, Beckers S, Mertens I, van Hul W, van Gaal L: The GI 422A variant of the cannabinoid receptor gene (CNRI) is associated with abdominal adiposity in obese men. Endocrine 2007, 31:138-141.

41. Benzinou M, Chèvre JC, Ward KJ, Lecoeur C, Dina C, Lobbens S, Durand E, Delplanque J, Horber FF, Heude B, Balkau B, BorchJohnsen K, Jørgensen T, Hansen T, Pedersen O, Meyre D, Froguel P. Endocannabinoid receptor I gene variations increase risk for obesity and modulate body mass index in European populations. Hum Mol Genet 2008, I 7:1916-1921.

42. Pagotto U, Marsicano G, Cota D, Lutz B, Pasquali R: The emerging role of the endocannabinoid system in endocrine regulation and energy balance. Endocr Rev 2006, 27:73-100.
43. Poster DS, Penta JS, Bruno S, Macdonald JS: Delta 9-tetrahydrocannabinol in clinical oncology. JAMA I98I, 245:2047-205I.

44. Gorter RW: Cancer cachexia and cannabinoids. Forsch Komplementarmed 1999, 6(Suppl 3):21-22.

45. Gross H, Ebert MH, Faden VB, Goldberg SC, Kaye WH, Caine ED, Hawks R, Zinberg N: A double-blind trial of delta 9-tetrahydrocannabinol in primary anorexia nervosa. J Clin Psychopharmacol 1983, 3:165-171.

46. Naruse $T$, Amano $H$, Koizumi $Y$ : Possible involvement of dopamine $D-I$ and $D-2$ receptors in diazepam-induced hyperphagia in rats. Fundam Clin Pharmacol 1991, 5:677-693.

47. Naruse T: Effects of repeated intravenous administration of diazepam on food intake in rats. Fundam Clin Pharmacol 1994, 8:379-384.

48. Hinney A, Bornscheuer A, Depenbusch M, Mierke B, Tölle A, Middeke K, Ziegler A, Roth H, Gerber G, Zamzow K, Ballauff A, Hamann A, Mayer H, Siegfried W, Lehmkuhl G, Poustka F, Schmidt MH, Hermann $\mathrm{H}$, Herpertz-Dahlmann BM, Fichter $M$, Remschmidt $\mathrm{H}$, Hebebrand J: No evidence for involvement of the leptin gene in anorexia nervosa, bulimia nervosa, underweight or early onset extreme obesity: identification of two novel mutations in the coding sequence and a novel polymorphism in the leptin gene linked upstream region. Mol Psychiatry 1998, 3:539-543.

49. Quinton ND, Meechan DW, Brown K, Eastwood H, Blakemore Al: Single nucleotide polymorphisms in the leptin receptor gene: studies in anorexia nervosa. Psychiatr Genet 2004, 14:191-194

50. Miyasaka K, Hosoya H, Sekime A, Ohta M, Amono H, Matsushita S, Suzuki K, Higuchi S, Funakoshi A: Association of ghrelin receptor gene polymorphism with bulimia nervosa in a Japanese population. I Neural Transm 2006, I | 3: | 279- I 285.

5I. Monteleone P, Tortorella A, Castaldo E, Di Filippo C, Maj M: No association of the Arg5IGIn and Leu72Met polymorphisms of the ghrelin gene with anorexia nervosa or bulimia nervosa. Neurosci Lett 2006, 398:325-327.

52. Ribasés M, Gratacòs M, Armengol L, de Cid R, Badía A, Jiménez $L$, Solano R, Vallejo J, Fernández F, Estivill X: Met66 in the brainderived neurotrophic factor (BDNF) precursor is associated with anorexia nervosa restrictive type. Mol Psychiatry 2003, 8:745-75I.

53. Ribasés $M$, Gratacòs $M$, Fernández-Aranda $F$, Bellodi $L$, Boni $C$, Anderluh M, Cavallini MC, Cellini E, Di Bella D, Erzegovesi S, Foulon C, Gabrovsek M, Gorwood P, Hebebrand J, Hinney A, Holliday J, Hu $X$, Karwautz A, Kipman A, Komel R, Nacmias B, Remschmidt H, Ricca V, Sorbi S, Wagner G, Treasure J, Collier DA, Estivill X: Association of BDNF with anorexia, bulimia and age of onset of weight loss in six European populations. Hum Mol Genet 2004, I3:|205-1212.

54. Ribasés $M$, Gratacòs $M$, Fernández-Aranda $F$, Bellodi $L$, Boni $C$, Anderluh M, Cristina Cavallini M, Cellini E, Di Bella D, Erzegovesi S, Foulon C, Gabrovsek M, Gorwood P, Hebebrand J, Hinney A, Holliday J, Hu X, Karwautz A, Kipman A, Komel R, Nacmias B, Remschmidt H, Ricca V, Sorbi S, Tomori M, Wagner G, Treasure J, Collier DA, Estivill X: Association of BDNF with restricting anorexia nervosa and minimum body mass index: a family-based association study of eight European populations. Eur J Hum Genet 2005, 13:428-434.

55. Friedel S, Horro FF, Wermter AK, Geller F, Dempfle A, Reichwald K, Smidt J, Brönner G, Konrad K, Herpertz-Dahlmann B, Warnke A, Hemminger U, Linder M, Kiefl H, Goldschmidt HP, Siegfried W, Remschmidt $\mathrm{H}$, Hinney A, Hebebrand J: Mutation screen of the brain derived neurotrophic factor gene (BDNF): identification of several genetic variants and association studies in patients with obesity, eating disorders, and attention-deficit/hyperactivity disorder. Am J Med Genet B Neuropsychiatr Genet 2005, I32B:96-99.

56. Ando T, Ishikawa T, Kawamura N, Karibe M, Oba M, Tatsuta N, Hara S, Takii M, Naruo T, Takei M, Kurokawa N, Nozoe S, Kubo C, Komaki $\mathrm{G}$ : Analysis of tumor necrosis factor-alpha gene promoter polymorphisms in anorexia nervosa. Psychiatr Genet 200I, I |: |61-164 